\section{Robinson og civilisationen}

JAN IFVERSEN

Daniels Defoes roman Robinson Crusoe (RC) fra 719 er ofte blevet sat i forbindelse med civilisation. ${ }^{\mathrm{T}}$ I719 er ofte blevet sat i forbindelse med civilisation. ${ }^{\mathrm{T}}$ den moderne civilisation..$^{2}$ Myten - robinsonaden skulle således gennemspille og stabilisere de centrale konflikter i den moderne, europæiske civilisation. Forskellige aspekter af civilisationsbegrebet er blevet trukket frem. Nogle har lagt vægt på at begribe civilisationsmyten i RC gennem særlige områder a den moderne, europxiske udvikling så som det den moder eller det politiske 4 ng sà de fortlke bon $i$ lyset of de gralgt at for ningspoler i cullisationsbegrebet sà som bevægelsen fra natur til kulturs eller fra vild til civiliseret. Bogens rolle som bidragyder til en europæisk koloniideologi er blevet fremhæret. Det er ligefrem blevet hævdet, at dens mytologiserende fremstilling udkrystalliserer de bærende elementer $i$ en sådan ideologi. ${ }^{6}$ Ifølge denne opfattelse skulle bogen faktisk kunne læses som en fremstilling af de grundlæggende problemer i den europæiske kolonisering. Det har således ikke skortet på læsninger af RC, der satte den i forbindelse med civilisation. Men ingen har mig bekendt gjort selve civilisationsbegrebet til omdrejningspunkt for en fortolkning. Civilisation har typisk optridt som et $-\mathrm{ikk}$ beh. Civilisation har typisk opradt som et - ikce behandlet synony mere af en modere, enten det har varet under betegnelser som kapitalisme, individualisme eller kolonisering. Hvilken betydning det måtte have at bruge en term som civilisation, er jældent blevet diskuteret

Jeg vil i det følgende betragte RC som en tekst, der på forbilledlig vis iscenesætter de centrale side af civilisationsbegrebet. Det er min tese, at dannelsestemaet i romanen udformes i mødet mellem en individualistisk-religiøs diskurs og en etno-geografisk diskurs, og at dette møde bringer de to sider a civilisationsbegrebet sammen. Det er videre min ancollse tagelse, at Robinson-bogen må ses som et af de første og mest udfoldede eksempler på cementeringen af det semantiske felt, der betegnes med ordet civilisation $i$ midten af $1700-$ tallet. Selv om ordet ci-

\section{(}

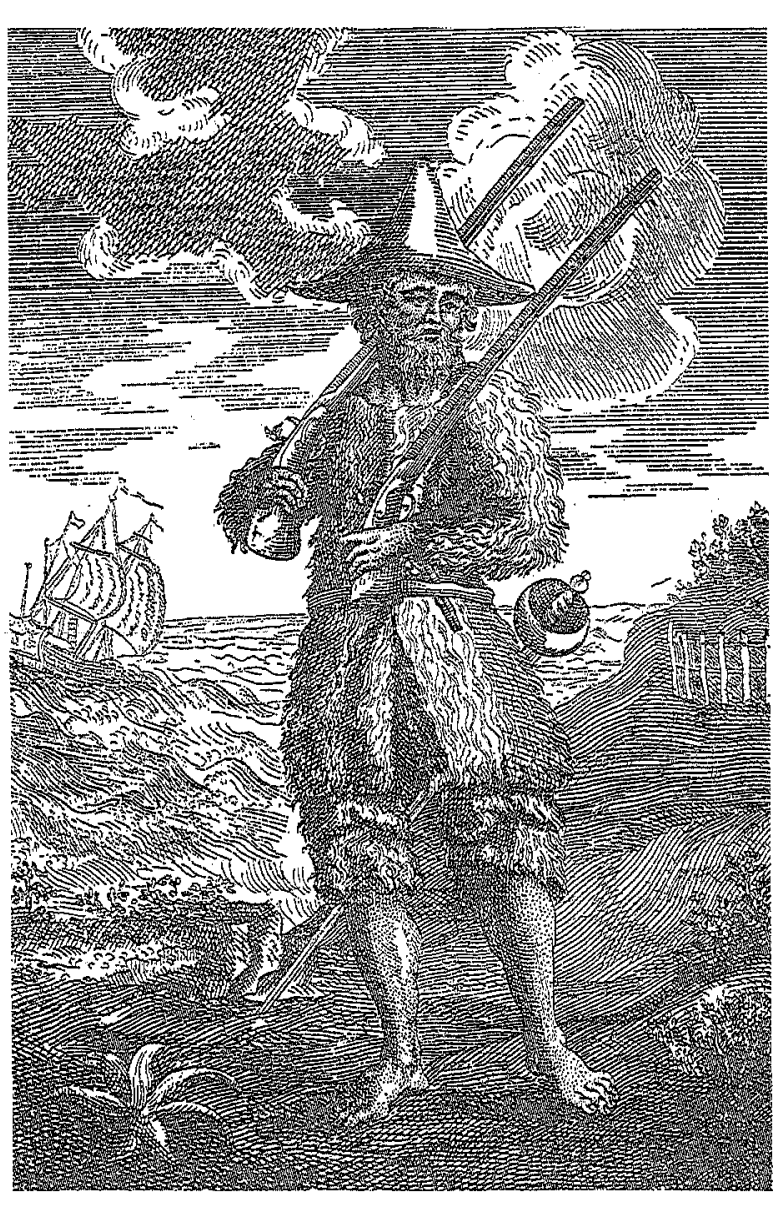

Frontispice til forsteudgaven af Robinson Crussee. den ved hjælp af andre ord de aspekter, der danner civilisationsbegrebet.

En diskurs om andethed og forskel

tt af elementerne i den etno-geografiske diskurs er sammen den og den geogren af remmede mennerker af fremmede steder. I 1700-tallet er etnografiske beskrivelser knyttet til opdagelser, som netop fremhæve det spatiale element, dvs. både rejsen og det fremmede steds geografiske plads. Mere præcist kan man sige, at opdagelsen forlener den etnografiske beskrivelse med et rum. Dette rum er både et abstrakt, geografisk rum, hvis typiske form er kortet, og et konkret rum, som omgiver opdageren/beskriveren. For at betone spatialiteten har jeg valgt at tale om en etno-geografisk diskurs.

Jeg hævder altså, at den grundlæggende skelnen i civilisationsbegrebet mellem udannet og dannet for lvor fir form $i$ en etno-geografisk diskurs, do

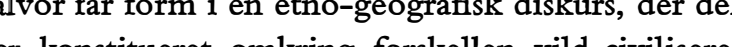
dels on dels omkring rejsen til de frommede. Det etnografske udformes 1 en ,andethedsretorik ", hvorigennem forskellige relationer til det anderledes kan femstilles. De forskellige relationsstrukturer udfoldes i de forskellige etnografiske beskrivelseskategorier. $\mathrm{He}$ klassificeres de vildes forskellighed efter bestemt kriterier. Etnografien drejer sig imidlertid ikke kun om at etablere forskelle. I kraft af den konstitutive skelnen mellem vild og civiliseret er den indskrevet $i$ en civilisationsfigur, hvor vægten både lægges pà forskellen dannet-udannet og på bevægelsen fra en tilstand til en anden. Derfor handler det også om hrorledes man kan bevere sig fa en tiltand tit hvorledes makn. anden, dvs. hvordan man kan blive dannet eller ci-
viliseret.

Opdagelse udgør et aspekt af den etnografisk fremstilling, nemlig i form af fremstillingens subjek tive moment. Etnografen er en opdager, eftersom han må rejse til det fremmede sted og beskue det forud for selve beslrivelsen. Den moderne etnogra som en videnskab og en genre opstår ganske vist ved at udviske opdagelsen. Opdageren og beskuere forsvinder til fordel for den anonyme beskrivelse, der alene refererer til bagvedliggende beskrivelsessystemer. Opdagerens forsvinden tager fart i 1700 tallets rejsebeskrivelser, hvor fortællerens eventyrlige tilstedeværelse i stigende grad adskilles fra den systematiske sædeskildring. ${ }^{8}$ Opdageren vedbliver imidlertid med at dukke op. Et af de steder, hvor te steder, hvor ther er i litteraten klassisk opdagers alloser. Her udspiller fremstillingen af $d$ fremmede sig omkring fortællerens eventyrlige tilstedeværelse.

Opdageren har et andet forhold til det fremmede end etnografen. Han har ikke samme greb om fo skellen. Derfor står han i højere grad over for andetheden. Andethed anvendes her til at betegne en oplevelse af det ukendte og fremmede, der rækker ud over det begribelige og beskrivelige. Forskel derimod forudsætter en beskrivelse, der kan sætte noget $i$ relation til noget andet inden for et beskrivelsessystem 9 Andethed er det, som dels gar forud for den diskursive bemesting af det fremmed forud for dereme, og som dels er knytet tilen Bevidsheden om denne tilstand, der er knyttet th opdagelsens eller mødets øjeblik, betegner Francis Affergan som en bevidsthed om det fjerne: „Bevidstheden om dette øjeblik er en bevidsthed om det fjerne i den forstand, at begribelsen af andetheden forudsætter tabet, det momentane fravær eller ophævelsen af ens orienteringspunkter".. .ro Bevidstheden om det fjerne er en anden type bevidsthed. Den ser noget andet end den bevidsthed, der er forbundet med forskelsbeskrivelse. Og netop „ser“", fordi den ifølge Affergan opererer inden for et ekspressivt meningsfelt bundet til synssansen. At andetheden perer vak fro det bescrivare, det der kan bemestres disk det beskrivare, det der kan berelatere den ii en bevided relatere den til en bevidsed on det feme, der er anderledes end beskivelens vidstheden om forskel som en bevidsthed om kvantitet påkalder alene et objekt i nerheden for at sammenligninger, substitutioner og kombinationer kan finde sted". ${ }^{\text {.x }}$ Over for denne logik udtrykker andetheden ,en modstand mod enhver reducerende bemægtigelse". ${ }^{12}$ 
Andethed hører til et ekspressivt erfaringsfelt, et fænomenologisk felt, der ikke lader sig opsummere $i$ et diskursivt felt. Men den bryder fra tid til anden gennem sproget: „Sproget berører grænserne for det genn usigelige, for ilk ". nikke "n Det ka kome rede beskiverser af deseremmest lægges vægt på diskrepansen mellem den seende og det sete. Det kan også være ved markører, der har til funktion at markere det ubegribelige. Typiske markører herfor er betegnelser, der henviser til det underfulde eller det redselsfulde.

Andethed lnytter sig til opdagelsens øjeblik, forskellen derimod hører sammen med en efterfølgende tagen $\mathrm{i}$ besiddelse. Gennem beskrivelsen søges andetheden reduceret til forskel i et system, der kan begribes og bemestres. Beskrivelsen forudsmetter siledes, at det fremmede kan placeres i det kendte. kence. "For, at vare forke vare en smi i vormulerer det. 4 . opposition. Hvad enten den fenmede kan beskrives som en primitiv udgave af det samme, eller han er det modsatte af det samme, făr han betydning $i$ forhold til det samme. Beskrivelsen udformes $i$ en retorisk strategi baseret på inversion, negation og graduering. Det fremmede kan således fremstilles som det modsatte af det samme (inversion), som en ikketilstand (negation) eller som en lighed på en skala af af forskelle (graduering).

Beskrivelsessystemer forudsætter udfoldede beskrivelseskategorier. Fænomener skal kunne rubriceres og generaliseres. Bevegelsen fra et varens- til

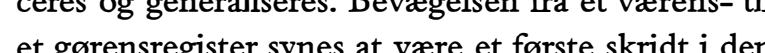

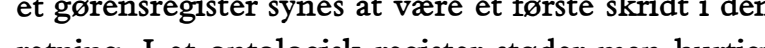
rething. I et on sylogisk register stoder man hurtigt

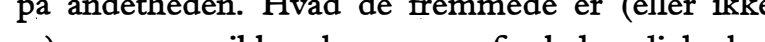
er), rummer ikke de samme forskelsmuligheder, som hvad de gør. Gennem beskrivelsen af de fremmedes gøren, deres sæder og skikke, udvides forskelsrepertoiret. Hvor opdagelserne placerer de fremmede i relation til generelle kategorier omkring det naturlige og unaturlige, opbygger etnografien beskrivelsesmønstre, der fra de simple gøremål så som spisevaner, boformer og seksualitet bevæger sig frem mod komplekse forhold omkring religion, po- litisk organisering, lovgivning og kunst. Med de systematiske „sædebeskrivelser" følger en udviskning af blikket og beskueren. Konsekvensen er, at de fremmede $\mathrm{i}$ højere grad objektgøres og generaliser. Ogsa i opdagelserne generaliseres der. Det er ter. Det er er de fremmede, han mødte i den nye verden, under betegnelsen indianer. Men generaliseringen vanskeliggøres af selve opdagelsen, der hele tiden lade konkrete indianere bryde ind i blikfeltet. Endvidere forbliver opdagelsens indianer en plastisk kategori, der lader sig bruge til forskellige formål, hvorimod etnografiens syntetiske indianer er fyldt ud med beskrivelser

Opdagelse og etnografi har med viden at gøre. De udfolder sig begge $i$ en vidensdimension, hvor det gælder om at begribe den fremmede. Men viden indskriver sig samtidig $i$ et felt, hvor det gælder om at bemestre den fremmede. Opdoeren og ethogra fen bide har or besaarel sige, at de ved at navngive handler 1 kraft af deres ses. ling $i$ al opdagelse, fordi den udtrykker en diskursi stabilisering. Nàr Columbus som noget af det forste giver de øer, han har opdaget, navne, der henvise til det kendte, er det for at fả dem på plads i sin videnshorisont. Navngivningen er led i et størr handlingskompleks omkring besiddelsestagning, de indbefatter religiøse og politiske begrundelser for at konvertere det opdagede. På vidensplanet er allerede navngivningen en form for konvertering, men den ledsages af en række religiøst og politisk begrundede handlinger, der skal drage de fremmede ind europæerens horisont. Det er denne konvertering, der er forbundet med civilisation.

Handlingsplanet kan belyses fra to sider afhængig af hvem der er subjekt for handlingen. I konverteringen er opdageren/etnografen subjekt. Det er ham, der overskuer, navngiver og konverterer $\mathrm{d}$ fremmede. Men de fremmede kan også give anledning til en reaktion fra opdageren/etnografen. Det sker netop, hvis den fremmede fremstår $i$ en radika andethed. Her trænger det fremmede ind på subjektet og reducerer det til en passiv recipient. Ganske vist forsvarer subjektet sig ved at ty til det un- derfulde eller rædselsfulde. Men ret beset er det betegnelser for, at noget er. uden for subjektets fatteevne og dermed uden for dets kontrol. På handlingsplanet vil subjektet $\mathrm{i}$ sådanne situationer handle affektivt og ikke rationelt, dvs. bemestrende. Man afelive vil derfor ogsa kunne alazse andetheden i de affektive hanivis der ledager andethed markører. Vi skal se nedefor, bvordan andethed i RC kan analyseres i en relation mellem syn, affekt og anvendelsen af andethedsmarkører.

Robinson Crusoe og de vilde

- mellem andethed og forsked

Den etno-geografiske diskurs, der omfatter opdagelserne og etnografien, opererer med tydelige, spatiale koordinater. Det fremmede vil være lokalisere et sted, hvortil og hvorfra man rejser. Rejsen spiller en vigtig rolle $i$ fremstillingen, hvor den udgor et narrativt skelet. Rejsen markerer saledes en rakke tilstandsskift mellem tilstanden hjemme os tilsta den den ude. Nar og komer il det fencer fet fremmede og kommer tilbage det hjemlige. Vi har dermed en klassisk fortælling om helten, der bryde op og vender hjem. Men rejsen har også en metaforisk funktion i opdagelsen, eftersom den kan bruge til at understrege løsrivelse (fra det kendte) og deraf følgende diskursiv ustabilitet: „I tilfældet med Nord- og Sydamerika blev denne følelse af løsrivelse fra alt, hvad der var kendt, mest tydeligt markeret af den første rejse: Det altid frygtelige og ofte skæbnesvangre togt over oceanet". ${ }^{\text {Is }}$ I RC har rejsen både denne metaforiske funktion og en narrativ funktion.

Rejsen er rammen om de øvrige spatiale koordinater. Rejsens mål, der samtidig er opdagelsens sted, er naturligvis rammen for selve oplevelsen og beskrivelsen af det fremmede. Oplevelsen, som virker inden for et ekspressivt meningsfelt, er i sig selv struktureret spatialt: det afgørende er, hvad man ser. Her spiller spatiale koordinater som perspektiv, nærhed/afstand, indenfor/udenfor en afgørende rolle. Blikket forudsætter en beskuer, der på sin vis udgør det punkt, hvorfra stedet bliver synligt. I det affektive handlingsregister, opdagelsen er knyttet til, vil dette punkt konleretisere sig som et egentligt sted, nemlig i opdagerens krop. Vi har således to lokaliteter, der bindes sammen af blikket: kroppen og stedet.

Oplevelsen af andethed kan i RC analyseres i anvendelsen af spatiale koordinater. Ser man et øjeblik bort fra rejsen fra hjemmet (eller rettere rejserne), ${ }^{16}$ så har vi i romanen tre lokaliter: øen, havet uden for øen og Robinsons øhjem/krop. Centrum er Robinsons øhjem/krop. Indenfor/udenfor og nærhed/afstand måles fra dette centrum. Andethed kan således måles $i$ afstand og bestemmes som det udenfor. I den europæiske kultur markerer det eksterne og det fjerne samtidig det barbariske. ${ }^{17}$ Som vi skal se, fremstilles andethed i RC primært ved hjælp af de indtrængende kannibaler, der repræsenterer den mest absolutte form for barbari.

Andethed metaforiseres $\mathrm{i}$ tre billeder: havet, den vilde natur og kannibalerne. De tre billeder repræsenterer det farefulde og kaotiske, der truer med at reducere Robinson til et passivt objekt. Havet udtrykker den kraft, der konstant sætter en stopper for Robinsons bestræbelser på at styre og bemestre. I fortællestrukturen fungerer havet som Robinsons modspiller. Robinsons eventyrlyst (hans indre kraft) imødegås af havet, der $\mathrm{i}$ form af frygtelige storme (romanen tæller mindst 4 storme) eller blot dets almindelige styrke (strømmen) forsøger at udslette Robinson. Havets karakter af andethed viser sig dels i det affektive register, hvori det optræder, dels dets karakter af ubegribelighed. Stormene fremstilles især gennem det ekspressive meningsfelt, hvor syn og affekt dominerer. Under den forste storm ved En ands astkyst bliver Robinson frebet or skretkeliget af den „magen til uhyggeligt syn jeg aldrig har set“ (2I). Robinson befinder sig videre $i$ en tilstand, ,jeg ikke er i stand til at beskrive" (22; min fremhævelse). Under den storm, der ender med det berømte skibbrud, frygter Robinson at blive "opslugt“" (53) eller alternativt at blive "ædt af vilde“ (54), hvis skibe driver på land. Her glider havet, der i øvrigt betegnes ,det vilde hav (SS), sammen med en anden andethedsfigur, kannibalerne eller de vilde (savages). Det understreges endvidere, at Robinson har „,begi- 
vet sig det vilde hav (...) i vold“ ( $(5 s)$. Og da han til slut kastes ud i havet, er vi igen uden for det beskrivelige: ,intet kan skildre den forvirring, der greb mig da jeg blev slynget i havet" (56). Robinsons relatio til havet ligger uden for diskursiv kontrol. I fortæl lestrulture fremsilles dette som fortall I fortællestrukturen frem servation af hovedpersonens manglende selvreflek-

Vi genfinder forbindelsen mellem affektiv reaktion og ubeskrivelighed flere steder $i$ romanen. Igen $i$ relationen til havet $i$ en scene, hvor Robinson sejler bort fra sin $\varnothing$ og ud på havet: „Det vil være vanskeligt at forestille sig, hvor bestyrtet 'jeg nu ... (I54). I mødet med øen, der er genstand for overvældende glæde:

Da jeg nu var gået i land i god behold, rettede jeg blikket opad og takkede Gud, fordi mit liv var blevet sparet i en situation, hvor der for blot fâ minutter siden knap havde varer mulighed for hab Jeg anser det for umuligt at give en fildestgarende beskrive for hab. Jo (blevet reddet fra graven. (58. min fremherelse).

Men øen i sin egenskab af vild - repræsenteret ved vilde dyr - kaster samtidig Robinson ud i „,en så forfærdelig angst, at jeg en stund løb rundt som en afsindig" ( 59$)$.

Det er imidlertid i mødet med kannibalerne, a andetheden fremstilles tydeligst. De vilde og kannibalerne ${ }^{\mathrm{r} 9}$ optræder som et konstant element i Robinsons kulturelle viden. Inden mødet optræder de vilde kun som en generel reference for det farefulde ukendte. Robinson må antage, at der uden for øen (eller skibet) befinder sig grusomme vilde. Selve mødet former sig som en proces af tiltagende mødet former sig som en proces af tiltagende nær hed. De konkrete vilde befinder sig først som e fern horisont for Robinsons blik. Interessant no dukker de forst op, efter at Robinson ikke længere kan føre dagbog over sin øtilværelse, fordi hans blæk slipper op. Han befinder sig altså her uden for skriftens trygge kontrol. Det, at de vilde kommer nærmere Robinson, kan læses som en erkendelsesmæs sig bestræbelse på at begribe og bemestre andetheden. Tilnærmelsen foregår imidlertid i det affektive register. Synet af fodsporet $i$ sandet gør
Robinson „lamslået, som om jeg havde set et spøgelse“, „aldeles forvirret, ja ude af mig selv" "slagen med rædsel“ (r68). Fodsporet er et tegn på andethed, Robinson kan hverken se eller tyde, hvilket modsvares af, at han er „ude af sig selv“, altså netop i det udenfor, der tilhorer andetheden. Det efterfande sym af hjerneskaller of andre rester på strande tigen Robinson ud af fatning., følelser som jeg umuligt kan beskrive, for jeg så. at stranden var oversået med kranier og knogler af hænder, fødder og andre dele af flere menneskelegemer" (178-179). Det understreges, at Robinson aldrig har set den barbariske andethed, han har hørt om tidligere:

Alle mine følelser var opslugt af tankerne om en sådan afgrund af umenneskeligt, djevelsk barbari og af menneskenaturens udartning. Nok havde jeg i sin tid jevnlig hort om sligt, men aldrig varet kendsgerningen på nert hold (I79; min fremhevelse).

Selv om den barbariske andethed stadig kun befinder sig i Robinsons synsfelt, begynder den langsomme indskrivning af andetheden. Tilnærmelsen er således udtryk for en gradvis bemestring. Det modsvares af den renselsesproces, Robinson gennemgår ved synet af andetheden. Han kaster op og bliver lettet. Opkastningen må ses som en invertering af kannibalernes indtagelse af mennesker. Robinson udstøder af sin krop, hvorimod kannibalerne indtager lroppe. Udstødelsen er som næunt tidligere den aktive måde at omgås det barbariske på. Efter udstødelsen kan Robinson genvinde det selv ( jeg fattede mig"), der er grundlaget for at lumpe bemestre and te andetheden. I modsatining til fodsporsscenen er ty heden. Fa de forstilge tegn $i$ form af skeletrester deducerer han sig frem til, hvad der er gået for sig. De følgende etaper i Robinsons møde med de vilde er fremstillet som en gradvis tilnærmelse kulminerende med den konkrete vildes, Fredags, indtog på scenen. Kannibalerne træder ind i Robinsons synsfelt: „Man vil vanskeligt kunne forestille sig, hvilken skræk dette syn fremkaldte hos mig, navn- lig at de vilde nu var kommet til min side af øen og tilmed $i$ så ringe afstand fra mig" ( $196 ;$ min fremhxvelse). Endnu befinder de sig uden for beskrivelsen .Jeg kunne i ovrigt kun se, at de var splitternøgne...." (197; min fremhævelse). Nøgenhed er en klassisk topos $i$ fremsillingen af de fremmede klassisk topos i fencillo den nye verden. Betegnelsen tjener dels til at be gisk (de er ren natur o har derfor ingen kultur), dels til at markere beskuerens rådvildhed overfor andetheden. I det sidste tilfalde er nøgenhed et tegn for, at den fremmed undslipper enhver beskrivelse. Affergan taler om nøgenhed som „det stumme mærke for en frygtelig tomhed“. ${ }^{20}$ I RC forstærkes "den frygtelige tomhed" netop af forbindelsen mellem nøgenhed og kannibalisme. Det er det sidste, der gør nøgenheden frygtelig og rædselsvækkende.

Det første skridt i retning af en bemestring af de fremmede finder sted $i$ en rent moralsk diskurs. Robinson diskuterer med sig selv, hvorvidt han ret til at falge ret til at folge in lyst in at drabe kannibalerne. $P a$ den ene side fenctrose (,en sådan umenneskellg tilstand (210), og unaturlige (,disse indfodtes naturstridige stikke), på den anden side som uskyldige og uvidende (,,De anser det ikke for en forbrydelse at dræbe en krigsfange, lige så lid som vi synes det er en forbrydelse at slagte en okse $(\mathrm{I} 85))$. De fremmede får dermed plads $i$ en morals diskurs som barbariske og uskyldige, hvorved andetheden inddæmmes. Det barbariske kan forankres en betydning, der beror på en inversion (menneskelig-umenneskelig) samtidig med, at de fremmede udstyres med en vis primitiv rationalitet (for dem er kannibalisme naturligt). I sit moralske resonnement må Robinson po sin vis sette sig ind $i$, bvordan verden ser ud for de fers den nå frem til en bestacere dem $i$ et ontologisk register som primitive og tidig placere sig selv moralsk i forhold til dem. Hvad romanen her gennemspiller er et eksempe på den moralske bemestringsstrategi, der ledsaged opdagelserne, hvor andethedserfaringerne kunn ophæves ved religionens hjælp. Med henvisning til kristendommen kunne opdageren legitimere sin egen position som bemestrer og, hvad der var vigti- gere, fremstille de fremmede som konverterbare. Nøgenheden overgår dermed fra at være frygtelig (dvs. ubegribelig) til at være et nulpunkt, som der kan begyndes. fra. Kunsten består i at flytte umenneskeligheden fra det farlige og moralsk forkastelige til det uskyldige. Det er netop hvad Robinson ror, åben.

Den moralske bemestring retter sig primært mod at skabe en subjektposition for bemestringen. Beskrivelsen af de fremmede er ikke afgørende, blot de kan indskrives $i$ en inversion og dermed gives en lavere status. Selv om (eller måske netop fordi) Robinson har afklaret det moralske forhold, der forbyder ham at destruere de fremmede, men nok giver ham ret til at tage en af dem $\mathrm{i}$ besiddelse, står han stadig uvidende over for deres gøren: „men de dansede med et utal af barbariske krumspring og gebærder omkring ilden" (215). Denne uvidenhed hæn ner sammen med den ontologiske sikkerhed, Robinson har fet Robnot har faet Tigerent da den konkrete fremmede træder ind på scenen og udfordrer billedet af en fjerne, ontologiske kannibal.

Selve scenen, hvor Robinson redder Fredag fra kannibalerne, kan betragtes som en fremstilling af skiftet fra opdagelse til etnografi, fra andethed til forskel. Her fuldendes i bogstavelig forstand den tilnærmelse til andetheden, som er udtrykt i det gradvise møde med de fremmede: „ (Jeg) gjorde tegn til, at han skulle komme nærmere, hvilket han åbenbart forstod, for han gik et par skridt hen imod mig“" (217). Forståelsen ledsages af en direkte bemestring. Den fremmede er "min vilde“ (2r8). Bemestringen forlaber i to paralle spor. Et direkte, bvor ejendomsfor misk temer, og et indireke, hor bemesing biver et spary of om avivining og fortlkning ver et spørgsmål om navngivning og fortolkning. I udgangspunktet er Fredag en kannibal, han er „min vilde". Hans væren er for Robinson kannibalistisk. Han er nøgen, og han kommunikerer „med mangfoldige gebærder, som jeg ikke forstod“ “ 218 ). Men $i$ modsæatning til de ferne kannibaler indgâr "overfloden af fagter" $i$ en kommunikations- og for- 
tolkningsproces. Robinson fortolker fagterne samtidig med, at han beskriver og konverterer Fredag. V har altså her en trefoldig bemestringsproces: fortolkning, beskrivelse og konvertering. Robinson må indgå $i$ en kommunikation med Fredag, men kommunik munikationen foregar inden for rammerne af beskrivelsen/konverteningen. Det understreges i romanen l.a. ved, at den forega pa det engelsk, Robinson har lert Tredag. Ganske vist er det i kommunikationen, at Fredag fẩr mulighed for at indtage en subjektposition, og at romanen åbner op for at beskrive et vildt perspektiv. ${ }^{2 x}$ Men spørgsmålet er, om ikke disse åbninger kun tjener til at forstærke konverteringen. Således har fremstillingen af Fredags religion, der lægges i munden på Fredag selv, til formå at betone behovet for en kristen konvertering. Fredags tale viser den nødvendige og vanskelige civilisationsproces. Efter at Fredag har fortalt om sin religion og undret sig over den kristne, må Robinson afbryde dialogen, fordi han bliver overvaldet over civilisationsopavens omf civilisator Gud om at satte mig 1 stand til at undervise denne stakkels vilde pà grundig og helsebringende måde
(233).

Den første ordløse kommunikation afbrydes af en egentlig etnografisk beskrivelse, der sætter Fredag på plads. Jeg gengiver her Robinsons første og mest omfattende beskrivelse af de vilde, fordi den fremstår som et godt eksempel på en forste klassifikation:

Han var en mand af anselig fremtoning, med en smuk skikkelse og velformede sterke lemmer. Han var ikke for bred, men høj, og som alt sagt var han tiltalende af udseende. Jeg anslog ham til at vare godt femogtyve år. Hans ansigt var behaeliots slet ikke vildt og fendtliot, tvertimod var det serdetes mandigt og virkede ejendentugeligt nok mild tog fet serdeles mandigt og vinkde jen  og sort, 1 kke krollet som uld, panden hoj og bred, og øjnene udtrykte livfludhed og gnistrende intelligens. Hudfarven var ikke sort, men morkebrun - ikke den skidne, gullige og lidet indbydende slags brunhed, vi kender fra brasilianeme og virginierme og andre amerikanske indfødte, men en slags gyldeneller ferskenlod, som var meget kon, men ikke let at beskrive. Ansigtet var rundt og fyldigt, nesen lille og ikke flad som ne- grenes, munden velformet med smalle laber og regelmessige tænder, der var hvide som elfenben (219-220).

Klassifikationen angår forholdet mellem karakter/udseende/farve og race. Fredag er ,ikke helt sort" og heller ikke gulbrun, men er placeret $i$

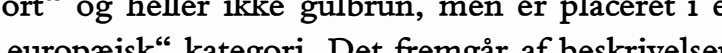

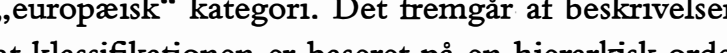
therarkisk orden a indfødte $i$ bunden. Det understreges af den tydelige aksiologi, hvor "mildhed“ modstilles "brutal (fierce), og den gulbrune farve betegnes som "grim" og "kvalmende“.

Denne systematiske beskrivelse følger umiddelbart før selve navngivningen („Først lod jeg ham vide, at hans navn skulle være Fredag“, 220), de netop skal placere den konkrete kannibal i sproget og dermed i beskrivelsen. Samtidig markerer navngivningen det punkt, hvorfra konverteringen kan begynde. Beskrivelsen og konverteringen forløber parallelt via en simpel inversion of en rakke forløber parallelt via en simpel inversion af en række grund(a) og religion. Freda er nøgen og gives klæder (hvorved selve spejlingsfguren mellem den nøgne uciviliserede Robinson, der kastes op på øen, og Fredag allerede antydes) Han spiser menneskekød og lærer at spise kogt dyrekød. Han har kun fagter og gives et sprog. Han har en forkert og simpel religion og omvendes til kristendommen. Inversionen fremstilles som en bevægelse indeholdende såvel aflæring som indlæring. Centralt i omvendelsen er bevægelsen fra kannibal til ikke-kannibal. At denne bevægelse går forud for den ideologiske omvendelse til „god kristen“, demonstrerer dens centrale plads i civilisationsideologien. Andethedens kerne lokaliseres således $i$ kanniblismen. Forst nor den ber sprængt, kan selve konverterngen begynde. Forst efter at Robinso $m$ det civilisered måltid i form af kogt og stegt dyrekød, kan Fredas forsikre, at han aldrig mere vil spise menneskekød. Civiliseringen finder sted $i$ de forskellige grundkategorier og fuldendes $i$ etaper. Påklædningen ender med at gøre ham „næsten lige så velklædt som sin herre" (222). Det kogte og stegte kød fầr han smag for. Sproget begynder han at beherske „gan- ske godt“ (227), omend det forbliver "gebrokkent engelsk" (235), hvilket i fortællingen demonstere gennem hans staccatoagtige syntaks, der bl.a. frembringes ved en konsekvent forkert ordstilling. Kristingen bliver en overvaldende succes: Den vilde dre end jeg" (234) fuldendelse betones $\mathrm{i}$ to markante passager. I den ene anerkender Fredag Robinsons position som civilisator. I Fredags "gebrokne engelsk“ lyder anerkendelsen sådan: „Du gøre en hel masse meget godt, lære vilde mænder være gode, pæne, tamme mænder" $(240) .{ }^{22} \mathrm{Her}$ kondenseres hele civilisationsprocessen. Vi har de civiliserende subjekt (den, der lærer fra sig), det uciviliserede objekt (den vilde mand) og selve processen i form af bevægelsen fra vild til tam. Clou'et er naturligvis, at civilisationen er lagt i munden på objektet. Med objektets anerkendelse er civilisationen fuldendt.

Den anden passage, der markerer fuldendelsen, handler om Fredags frygt for de indtrengende nibaler: nibaler: ,....jeg kunne se, at han var slememt fra vid og sans (...) Han rystede over hele kroppen, og jeg vidste lnap, hvad jeg skulle stille op med ham (244-245). Den andethed, som Fredag tidligere var en del af, frembringer nu præcis den samme affektive reaktion, som Robinson udviste tidligere (men som han i sin egen fuldendte bemestringsposition er kommet over). Fredag er med andre ord bleve fremmed over for sin tidligere tilstand.

Fuldendelsen kan imidlertid ikke ende med, at Fredag kan indtage den samme position som Robinson. Nok leges der med denne position i romaen. Fredag lan $\mathrm{f}$ eks. fremstå som en bedre kristen. Men dette fortin skal ses $i$ lyset of Fredags bristen. (n) ærlighed (,,Han kentes ily til luned, tvær(2) in (223); ,... alt, hvad han sagde, var så ærligt og troskyldigt" (238). Fredag er barnet, hvad der naturligvis placerer subjektet i faderens rolle: „hans følelse for mig var i enhver henseende som et barns for en far" $^{\prime \prime}$ (223; min fremhævelse). Fremstillingen af de fremmede som børn er en kendt figur i opdagelserne. Figuren gør det muligt at bringe de fremmed fra en radikal andethedspostion til en position af pri- mitivitet og underlegenhed, altsă til en position, der kan bemestres. I RC kan barnefiguren desuden indpasses i det generelle bibelske tema omkring den fortabte søn, hvorigennem civilisationen også gennemspilles.

Fredags fortrin relativeres endvidere af hans lavere position $i$ andre kategorier, ikke mindst $i$ sproget, som hy i konverteringen er som nævint, hvem der behersker sproget. I romanen er denne beherskelse dobbelt betonet, eftersom Robinson både indtager rollen som navngiver og fortæller. Kun i korte sekvenser ka Fredag indtage positionen som beskriver ( $i$ en diaog om hans religion), og da kun som materiale for Robinsons egen beskrivelse. ,Jeg sluttede deraf, at der er præsteskab selv blandt de mest forblindede os uvidende hedninger i verden " (23r $\mathrm{min}$ fremhævelse).

Bemestringen og kontrollen forløber $i$ såve

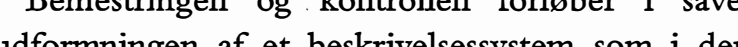
faktiske bement I systemet stal de for-

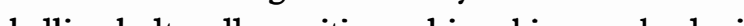

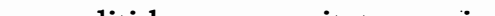
timerer Robinsons politiske suverænitet og ejendomsret over øen. En række positioner sættes pa plads $i$ løbet af romanen. Vi har forskellige social positioner, der defineres i forhold til faderens plads i midten som „middelstanden“; vi har forskellige nationale positioner inden for det europæiske (englændere, spaniere, portugisere); vi har forskellige religiøse positioner (hedninge, muslimer, katolikke og protestanter); endelig har vi som den overordnede ramme forskellen mellem uciviliseret (kannibaler) og civiliseret (Robinson) med Fredag $i$ mellemposition mellem de to yderpunkter. Gennem (nennem undmodsæt-

Grundmodsætningen markeres gennem hele romanen af de to yderpositioner, kannibalens og Robinsons. Selve civilisationsprocessen kommer til udtryl i mellempositionen, hvilket forudsætter en relativering af den uciviliserede position, men egentlig ogsa af subjektpositionen. Relativeringen sker gennem en opløsning af grænser. Kannibalens position kan relativeres på flere måder. Vi har allerede set, hvor- 
dan det kan ske i form af Fredags rolle som overløber og $i$ begyndelsen som en slags go-between, der indeholder elementer fra både det uciviliserede og det civiliserede, f eks, ved at vare vild og kristen. Samme monster kan etableres for Robinsons ved Samme Robins entkommende. iklæde barbariske fonmer. Robinsons berømte, hjemmelavede klædedragt er et billede på en - nærmest komisk - problematisering af subjektpositionen: „Men hvis nogen i England havde mødt en mand af mit udseende, ville jeg enten have gjort den pågældende meget forskrækket eller fremkaldt høj latter" (I63). Robinsons uengelske påklædning betegnes desuden som ",af den mest barbariske form“ (164). I modsætning til de barbariske vilde er Robinsons barbari dog ikke knyttet til kroppen/sjælen, men til det udvendige.

Robinsons position er indskrevet $i$ en mere omfattende civilisationsposition. Han er englender, europeer og listen. Englud optrot hover, ligt som ligt som den hjenlige efainthorisont, hvorfra Robinso de fortage same øerfaringer. Europa optræder dels som en mere abstrakt beskrivelseshoirsont, dels som kontrastpunkt til de vilde. Samme rolle spiller henvisningen til kristenheden. I selve civilisationsprocessen er det imidlertid alene kristenhed, der betegner målet. Fredag bliver en god kristen, ikke en god europæer. Den europæiske position er desuden tvetydig, fordi der etableres en forskel mellem Spanien og Robinson/England. Således kan Spanien flyttes frem og tilbage mellem det barbariske og det civiliserede. Med henvisning til den sorte legende ${ }^{23}$ gøres spanierne til værre barbarer end de vilde barbarer: spaniernes barbarike adferd i Amerika ( ) ,...sp de

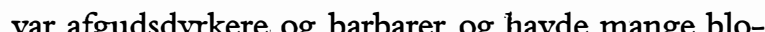
dige og barbariske ritualer, som for eksempel at ofre mennesker til deres afguder, men som i forholdet til spanierne var aldelses sageløse" (I85). Ved at placere spaniernes barbari i fortiden kan Robinson imidlertid atter bringe dem ind i civilisationen. Omgangen mied den konkrete Spanier, Robinson redder fra kannibalerne, tjener da også til at demonstrere et civiliseret fællesskab over for såvel de vilde som over- løberne. Spanieren „var europæer, og han havde tøj pä“ (247). Han er "den stakkels kristne“ (247), der identificerer sig over for Robinson med betegnelsen "Christianus" (249). Påklædtheden - det generelle civilisationsteon - forbindes med Europa mens kristenheden bruges til at betegne det kommukriscallestive er ereses at, at Robinson the "en alvonlig samale (256) med spanieren, og at han lader ham forpligte mulige spanske redningsmænd skriffligt: "Jeg medgav ham skriftligt et strengt pålæg" (26I). Skriftligheden er den priviligerede kommunikation mellem civiliserede, som Fredag ikke har adgang til. Skriftens betydning $i$ civilisationen er allerede betonet $i$ romanens form som en tekst skrevet af den tilbageskuende Robinson, der bl.a. henviser til den dagbogsoptegnende Robinson. Den dobbelttydige fremstilling af Spanien rokker

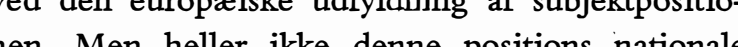
Me engelske mytterister, der lander på øen i den sidste del af Robinsons øophold, beskrives som barbariske og næsten kannibalistiske. Synet af, hvordan de behandler deres fanger, udløser rædsel hos Robinson: „(Jeg) stod blot skælvende af rædsel ved synet“ (265). Fredags spørgsmål om, hvorvidt de vil æde fangerne, må han dog svare nej til. Den magiske grænse mellem ægte kannibaler og barbarer bliver ikke overskredet. Engelske „banditter“ (265) kan ikke sammenlignes med kannibaler.

Hvad er så formålet med den indbyggede tvetydighed i subjektpositionen? Det er at styrke civilisationens position, eftersom subjektpositionen $i$ forlo bet rest pos i forloSpanier sletter den sorte legende. De brave englænOg Robho sobivson vinder over mytteristerne. g Robinson selv kan indtage positionen som det absolutte subjekt, der kontrollerer begivenhederne. Han er ikke kun øens „guvernør", „kommandør og „fyrste“, men indtager også en næsten guddommelig status. Da Robinson undsætter den tilfangetagne engelske kaptajn, udbryder denne: „Taler jes med Gud eller menneske? Er det et rigtigt menneske eller en engel?" (268) Som vi skal se i næste afsnit, er denne sekvens af central betydning som samlingspunkt for de to bærende civilisationsperspektiver, det etno-geografiske og det individuelle. I første omgang skal det kun fremhrves, hvordan den lukker de omalte hulleri subjetancivilisation fuldendes og lnytes sandil Engand, hvilket understeges af det sar, han giver kaptajnen: "Jeg er nemlig kun et menneske, englæn-

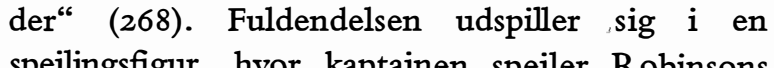
spejlingsfigur, hvor kaptajnen spejler Robinsons eget forløb.

\section{Robinsons $\sigma$}

I opdagelsernes og etnografiens diskurs fremstilles den strukturerende dikotomi mellem vild/barbarisk og civiliseret i en spatialiseret form. De to positioner tænkes som steder, der er adskilt af en grænse. Men diskursen skal ikke kun etablere granser. Den skal også iscenesntte en grenseoverkridelse, vel væelse fra den punktet i civilingerelse. en opdagelsesdishurs eller en etnografsk diskurs, hvor opdageren eller etnografen indtager subjektpo- sitionen, tager det sig ud som en bevægelse fra det ferne til det nære. Det nære er både det genkendelige og det, der kan bemestres.

I RC udspiller denne bevægelse sig $i$ to faser, en passiv og en altiv. I den passive fase antoger bevagelsen latater af en thunde indtangen. Det fierne, der kommer nærmere $i$ form af de indtreng ende Her er der ale on en som radikat anderledes. Her er der tale om en omvendt civilisation, en afcivilisering, hvor civilisationssubjektet $i$ bogstavelig forstand risikerer at blive opslugt af det vilde og barbariske. Afciviliseringen og den medfølgende objektgørelse er imidlertid grundlaget for, at subjekte kan begynde civilisationsprocessen, som karakteriserer den aktive fase. I den aktive fase generobre subjektet sin subjektposition. I RC sker det $i$ alle de registre, hvorigennem civilisationen udspiller sis. Robinson bearbejder den vilde natur og beler sig. de indreng de indtrængende kannibal diven ogs over on med dens dyr og planter, og 1 sidste ende over det fremmede, hvilket som navt giver sig ucslag 1 , at han skifter fra at være eventyrer/opdage til at blive etnograf.

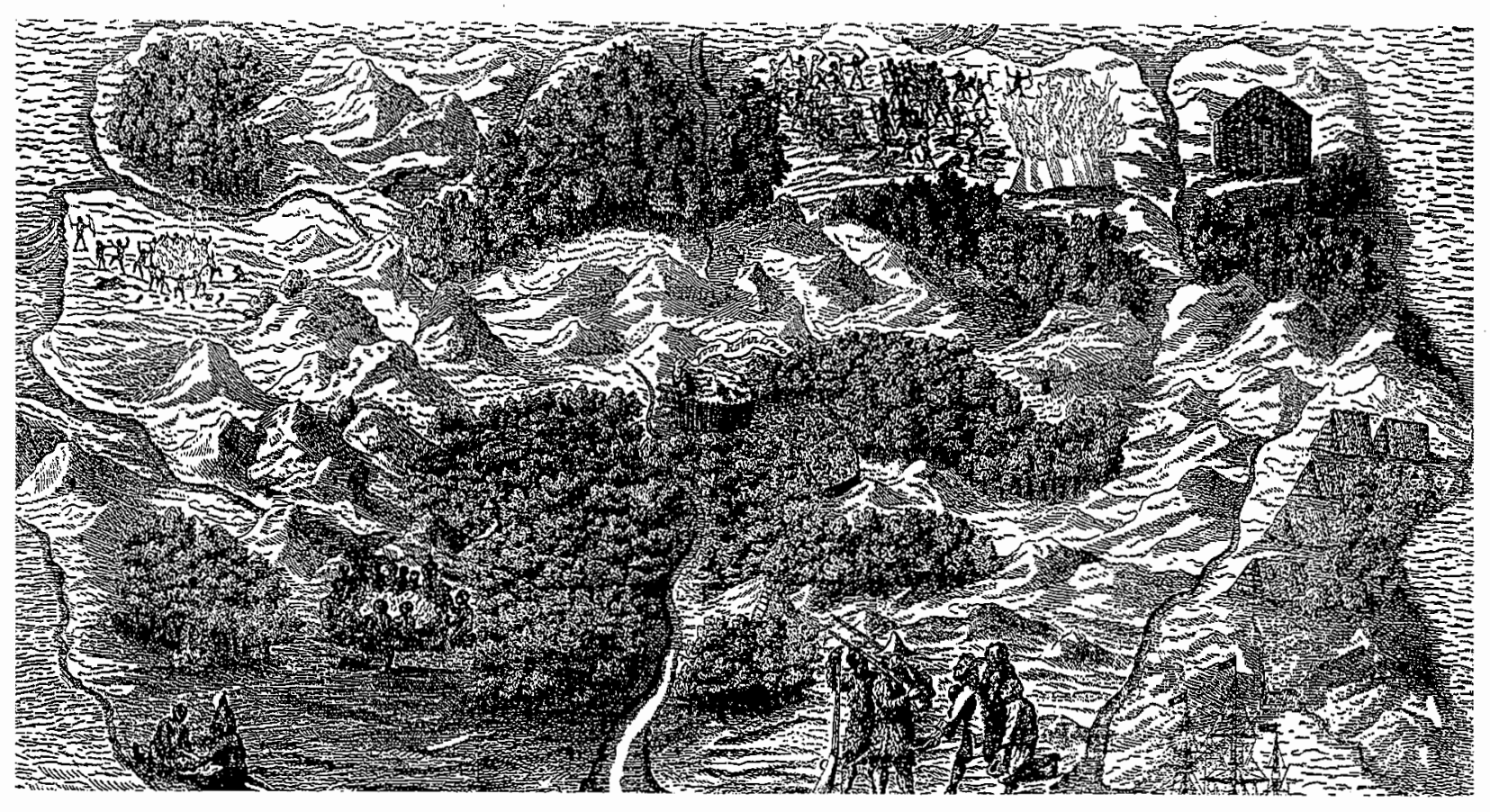

Kort over Robinsons ø. Fra 3. del af forsseudgaven 
I begge faser af bevægelsen udgør øen det metaforiske omdrejningspunkt. I den passive fase udtrykker øen det vilde i form af såvel det barbariske som det udyrkede. Det barbariske er øens ukendte side, der bemægtiges gennem Robinsons talrige opdagelsesrejser. Som en rete opdger kortleger Robin sesrejser. Som en agte opdager kortlægger Robinson øen, der dog wed at abenbare barbariske tegn. Bestrabelseme pa at kortlægge øe fremstilles $i$ to spatiale koordinatsystemer, et horisontalt og et vertikalt. På rejserne kæmper Robinson sig frem horisontalt til den anden side af øen Han er opdageren, der er kropsligt impliceret i det vilde og derfor ikke kan etablere en epistemologisk distance. Samtidig søger han at skabe sig overblik ved at indtage de højeste steder på øen. Herfra kan han både løsrive sig fra det vilde og oveskue det. $\mathrm{Ci}$ vilisationen forudsætter et sådant overskuende subjekt. Romanen fokuserer imidlertid ikke kun på det vertikale overblik som et udtryk for epistemologisk bemestring, men demonstrerer ogsi, hvordun overblikket afdekker nye ukendte steder. Fra sine sigtspu sigtspuler nes sted. Bestigel af de hajeste ste således en dialektik mellem det overskuende subjek og det indtrængende vilde, dvs. mellem den aktive og den passive bevægelse, der først ender med subjektpositionens fuldendelse i den endegyldige civilisationsproces.

Dialektikken mellem subjekt (jeg) og andethed, der karakteriserer dannelsen, udtrykkes også i den konkrete bemestring og bearbejdning af øen. Gennem opdagelsesrejserne kortlægges øen, gennem arbejdet kultiveres den. Begge aktiviteter udtrykke de forskellige sider af civilisationsprocessen. Andetheden viser sig $i$ form af de farer, som gen nummer, heden viser sig $i$ form af de farer, som øen rummer, og de liner, naturen besidder. De indre rejser på øe udsiller rom, nuture. Øe fungrer soms rejse gentager sig: han forlader „sit hjem“, ledes ud på det farefulde hav, udsættes næsten for forlis og skylles op på øen igen. Forudsætningen for, at øen kan optræde som scene for Robinsons civilisation rejse er imidlertid, at den er blevet omformet til et hjem. Hjemmet er den pol, som giver rejsen retning "(jeg) følte det hele tiden under denne udflugt, som om jeg var på rejse og hjemmefra“ (124).

Hjemmet er rejsens begyndelsespunkt og må. Det gælder om at bringe hjem og komme hjem. Robinsons forbindelse med øen har karakter af en hjemligrorelse. Hans forste projekt er at byge festing for stykke for stykke. Selve " fastuingen "bestâr af en række halvcirkelformede palisader, der klart metaforiserer strategien med at "indhegne“ det vilde. Fæstningen kulminerer $i$ en grotte, der som en anden livmoder udtrykker den ultimative beskyttelse. Senere følger indhegningen af dyr og marker. Indhegningen ledsages af kultivering. Gennem sit arbejde transformerer Robinson den vilde $\varnothing$ til en civilisation. Civilisationen udspiller sig her $i$ en vekselvirkning mellem Robinsons kunnen og øens ressourcer. Men det er Robinsons rationelle kapacitet og arbejdskraft, der udgør den udslagsgivende faktor. Den vilde natur lader sig velvilligt teme. Hvor ind vilde natur lader sig velvilligt tamme. Hor indhegningen er indadiveringen ekspansiv. I diege hjemlige øer $\mathrm{i}$ det fremmede og mod at beskytte sig mod det fremmedes indtrængen (eller penetration af den hjemlige livmoder). Kultiveringen er for så vidt en udvidelse af indhegningen, hvor mere og mere vild natur inddrages. Begge de to strategier kulminerer $i$ hjemliggørelsen, hvor fæstningen bliver til det hjem, hvortil alt „bringes hjem“. Robinson kultiverer og bringer hjem.

Sammenhængen mellem indhegning, kultivering og hjem er rodfæstet i europæisk mentalitet. Det civile er forbundet med civis, bylivet, der $i \mathrm{kraft}$ af bymuren afgrenser sig fra det barbariske liv udenfor mign byen. For europæeren er den vilde det hjemløse menteske, homo sylvestris, der lever uden for bylivets sociale sammenhæng. Byens mure beskytter mod det vildes indtrængen og opløsning af det civile liv. For at kunne orientere sig må europæeren derfor skabe hjem. Hjemmet er imidlertid også forbundet med ejendom i den europæiske horisont. Hjemmet er ens ejendom. Hvis en ting er ejendomsløs, har ingen ret til den. Den ejendomsløse ting vil kunne cirkulere fra hånd til hånd. Først når man hævder sin ejendomsret, vil tingen blive noget for en. I den europæiske forstålse af ejendom kommer man førs og fremmest $i$ besiddelse af en ting, hvis man har bearbejdet og indhegnet den:

Så meget land som et menneske plojer, tilplanter, forbedrer os dyrker og udnytte afgrodeme fra, så meget er hans ejendom Han inddrager det således gennem sit arbejde fra det falles. 24

Ejendom er for Locke et produkt af arbejde og indhegning, præcis som det er for Robinson. Indhegningen er derfor „mit eget hus“:

Det var overordentlig tilfredstillende for mig at komme tilbage til min gamle hytte og ligge i hængekejen. Denne lange fodtur, hvorunder jeg ikke havde haft fast bopæel, havde været sa strabadserende, at mit eget hus - som jeg ved mig selv kaldte de -i sammenligning forekom mig at vere en ideel bolig. (I2s min fremhævelse).

I tråd med den europæiske tankegang kan Robinson flytte indhegningen, kultiveringen og hjemliggørelflytte indhegningen, kultiveringen og hjemliggørel-
sen af øen op på et højere, politisk niveau. Øen kan da af øen op pà et højere, politisk niveau. Øen kongerige: ,....tanken om, at dette tilda blive hans kongerige. ",....tanken om, at dette tihørte mig - at jeg var den ubestridte konge og herre over hele dette land og ejede retten til at besidde det, ganske som en herremand i England ejer sit gods" (II3). Romanen følger således den linie, der karakteriserer europæernes omgang med besiddels og beherskelse af det fremmede: kultivering, ejendomsret, suverænitet, dog med den lille, ekstra dimension, at fremstillingen har et klart parodisk skær. Robinsons kongeværdighed er lattervækkende, som hele hans miniature-civilisation er det.

Øen fremstår som udganospunkt som middel og Øen for for civilisationspel og som man udfylder rollen som det nution $m$ udgà. Nulpun net rummer afslutningen af et forløb, der resulterer i ophøret betydning. Og det markerer et begyndelsespunkt. Robinson kastes $i$ land pa øen frataget næsten alle tegn på civilisationen. Øen er uopdyrket og ubeboet. Som den nøgne kannibal repræsenterer den civilisationens ophor i form af den absolut asociale tilstand. Da Robinson første gang fâr tid til at gennemtænke sin situation pà øen, gør han det i form af et veritabelt regnskab over det onde og det gode ved situationen. Under det onde fremhæves, at (j)eg er skilt fra menneskeheden, aldeles ensom, forvist fra menneskenes samfund“" (74). Den øde $\varnothing$ udtrykker ,adskillelsen fra menneskeheden “, dvs.

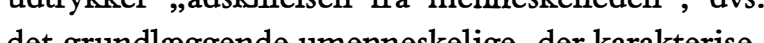
der bo rer bres. Dens tonneskets, det sociale menneskes død. Men tomheden er samtidig muligheden for at skabe. Mennesket kan skabe af intet. Øen er ogsa civilisationens tabula rasa, det begyndelsespunkt, hvorfra alle komponenterne kan genskabes. Den er scene for Robinsons geninstallering af alle civilisationens tegn. Gennem sin 'tilskrivning' af betydning til øen (via skriften og arbejdet) genfortæller Robinson civilisationens historie. ${ }^{25}$ Civilisationen er selve denne tilskrivningsog transformationsproces. I det 17 . århundredes samfundsteori blev civilisationens begyndelsespunkt tænkt som en naturtilstand, en ikke-socil tilstand, hvor men entstand, hor sig blolagge. Det civile og civiligede samfund lod sig begn naturtistanden kunne udstyres med sàvel barbariske træk som moralske kvaliteter. Robinson gennemspiller begge disse sider af naturtilstanden. Han er eneboeren, der hele tiden må kæmpe for at holde de barbariske træk i ave: ,Jeg, som befandt mig i naturtilstand“ (132), "Jeg handlede som et rent dyr alene ud fra naturens principper"(I03). Men han er samtidig skaberen, eller måske rettere civilisatoren, der i kraft af sin grundlæggende fornuft omformer et råmateriale. I det sidste tilfælde udspiller civilisationen sig i Robinson selv som en konflikt mellem den barbariske passion (afskylige or fordervede“" 18) og den civilisende 184) og den civilisende forme cillion begy $(78) .{ }^{26}$

Robinsons navnløse $\varnothing$ har utopiske træk. Den er måske ikke det ,intetsteds“" (u-topos), der etymologisk ligger til grund for utopien, men nok ,,detsted-hvor-alt-er-godt“" (eu-topos), der også indgik i Thomas Mores overvejelser, da han opfandt utopien. ${ }^{27}$ De utopiske træk manifesterer sig i skil- 
dringen af det gode samfund, Robinson er i færd med at skabe. Men netop ,i færd med“ i modsætning til den klassiske utopi, der beskriver et fuldt udfoldet utopisk samfund. I RC er utopien indsat en moderne civilisationsdiskurs, som betoner dels bevæoelsen fra en tilstand til en anden, dels skabe rens eller civilisatr (utere, brorvidt den

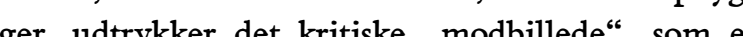
ger, udtrykker det kritiske "modbillede“, som er atopiens kerne. ${ }^{28}$ Snarere er den civiliserede $\varnothing$ et spejlbillede af den civilisation, Robinson er bleve udstødt fra. Nok hylder han fra tid til anden sin som et alternativt sted, hvor civilisationens negative værdier er ophævet. Således fremhæves det adskillige gange, at Robinson lever $\mathrm{i}$ et pengeløst og brugsorienteret samfund uafhængigt af pengenes fordærvende magt (,dette slemme, triste og nytteløse stads“ (r44); „Oh billige tant! sagde jeg højt hvad skal du nytte? intet er du værd“" (6g)). I et kritisk crescendo sammenfatter han sin utopiske ver den, som et sted lengt fra verdens syndighe

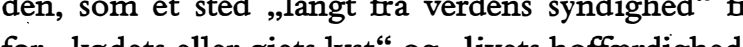
for "kodets eller "jets lys " og "livets hofardighed " (r43). Men denne purtanske vision har knap utop ens karakter. Den karakteriserer like en alternativ verden, med en tilstand af verdensfernhed og løsrevethed, der blot udgør den nødvendige negative side (løsrivelsen) forud for den positive genopbygning De forskellige kritiske udbrud og hyldester til det simple liv i romanen modsvares da også af skabertrangen, der bringer fortallingen frem mod slutpunktet, det fuldendte spejlbillede af det engelske samfund, øen som en koloni bestyret af „guvenøren" Robinson. Målet er ikke det simple liv eller løsrivelsen fra verden. Robinson forkaster nok limtvis pengene, ilke desto mindre gemmer ba glinvis pengene, itke desto gemmer ha dem og husker at ren og treder ind iden civilserede mulative orden (illustreret ved hjemrejse-sekvensen, der former sig som et veritabelt kapitalistisk eventyr). Civilisationskritikken dukker kun op momentvis, og da kun, fordi den skal fungere som den en pol $i$ det dynamiske spændingsfelt af nedrivning/nedskrivning/nulpunkt og opbygning/tilskrivning/begyndelsespunkt, der gør det muligt at fremstille civilisationsprocessens grundlæggende komponenter. I modsætning til samtidige og senere civilisationskritiske fiktioner har romanens puritanske visioner ikke til formål at skabe et modbillede og et punkt, hvorfra civilisationen kan kritiseres og rives ned. Tværtimod indsætter den det simple som den kerne, hvorfra det civiliserede udgår.

 Øen er ikke buritanske vision paradisiske karakter den selv en del heraf: „Her var alt să frisk, grønt o blomstrende, at det var som en evig vår eller blomstring og lignede en kunstigt beplantet have" (II3) Men selv Edens Have er her „en anlagt have“, der bærer civilisationens præg. Og Robinsons forhold $t$ denne have er utilitaristisk. Det drejer sig for har om at bringe havens frugter hjem, ikke om at nyde synet af frugtbarheden. Desuden er øen ingenlunde kun paradisisk, den er også vild, faretruende og djxvelsk. Det sidste udpensles i en scene, hvor Robinson bevæger sig ned i en mørk hule og pludselig ser to store skinnende ojne. Om de tilhorte et men" neske eller en djævel vidste jeg ikke“ (ror). ora djaverkaben kan udnyttes til brigbre formal len til et forråds

Øen udgør det spatiale centrum i RC. Den er såvel rammen om selve civilisationsprocessen som markering af grænsen mellem civilisation og ikkecivilisation. Samtidig binder den de øvrige spatiale koordinater sammen. I forhold til hjemmet markerer den et udenfor, der både er vildt og kan tæmmes. I forhold til det absolut vilde og barbariske form af havet eller kannibalerne i det fjerne - er øen et indenfor („min elskede ø“, I54). De spatiale koordinater tager sig ud som koncentriske cirler med hjemmet inderst og de ferne kyster ydert. I odfoldert. I udfolde forkellige cirler cantinen. Indhegingen og buttiveringen af øen transformerer den til et hjem, og samtidig inddrages kannibalerne i Fredags skikkelse i den hjemlige husholdning. Fredag bliver undersăt, tjener og arbejder i Robinsons hjem/samfund. Den endelige sammensmeltning sker imidlertid, da øen inddrages $i$ den europæiske horisont som en fuldendt kopi, en koloni, og dermed ikke længere markerer en grænse til civilisationen. I romanen de- monstreres det ved at lade hjemrejsen foregå $i$ et tomrum. Kun de lokaliteter, der har betydning for Robinsons berigelse er markerede.

Noter Noter
I. Romanens fulde titel er: The Life and Strange Surprizing Adventures of Robinson Crusoe, of York, Mariner: Who lived Eight and Twenty Years, all alone in an un-inhabited Island on the Coast of America, near the Mouth of the Great River of Oroonoque; Having been cast on Shore by Shipwreck, wherein all the Men perished but himself With An Account how he Jean Ducrocg: Relations de voyages et récits symboli2ues: Robinson et Gulliver“. Studies on Voltaire and the

Eighteenth Century. 25 . 1982 , p. S.
3. Ian Watt: The Rise of the Novel : Studies in Defoe, Richard-

son and Fielding. London, 1957 .
4. Maximillian E. Novak: Defoe and the Nature of Man. Oxord: Oxford UP, 1963 .

5. Claus Bratt Østergaard: Om køn og civilisation i det 19. arhundredes fiktion. København: Basilisk, 1987

6. Peter Hulme: Colonial Encounters. Europe and the Native Carribean, 1492-1797. London: Routledge, 1986, p. 886.
7. Her udger Claus Bratt Østergaards fascinerende diskus sion af Robinson $i$ et civilisationsperspektiv en undtagelse (op. cit.). Østergaard læser Robinson som et udtryk for en forste formulering af en moderne, borgerlig selvopfattelse, "en generaliseret forhandingsmodalitet" (ibid., p. I68). For ham er civilisation en analytisk betegnelse for en proces der leder frem mod det borgerlige samfunds realisering. 8. Gordon M. Sayre: Les Sauvages Americains. Representa Pes. Chapl Hill : The University of North Corolin Press, 1997, pp. 98-12

. De to erkendelseskategorier, andethed og forskel, er hentet fra Francis Affergan: „Les marqueurs de l'autre dans Robinson Crusoé. Contribution à la genèse $\mathrm{de}$ 'anthropologie de l'altérité", Les Temps Modernes, vol. 44 hr. 507, I988, pp. 22-45.

10. Francis Affergan: Exotisme et altérité. Essais sur les fondements d'une critique de l'anthropologie. Paris: PUF, 1987, p. 9. Ir. Ibid. Min fr
I2. Ibid. p. 83 .

13. Britta Timm Knudsen: Det synlige og det sigelige, Aspek13. Britta Timm Knudsen: Det synlige og det sigelige. Aspek-
ter af romanens asstetik og astetiske fanomenologier ifranse mo-
dernitet. Upubliceret Ph.d-afhandling. Aarhus Universitet 993. 4. Affergan: „Les marqueurs de l'autre dans Robinson Crusoé ...", op. cit., p. 39.

15. Anthony Pagden: European Encounters with the New UP, I993, p. 3.
I6. Robinsons rejse inden skibbruddet består af en serie af rejser med tydeligt markerede ophold (i London, i Nordafrika, i Vestafrika, i Brasilien).

17. Hayden White: „The Noble Savage Theme as Fetich“, Chiappelli, Allen and Beson (ed.): First Images of America, I8. Sidetallene heyviver of Califormia Press, 1976, p. I27. settelse af Robinson Crusoe, Daniel Defoe: Robinson Crusoe. Dansklærerforeningen I987.

I9. Savage optræder langt hyppigere end cannibal i romanen. Faktisk optræder sidstnæevnte substantiv kun fem gange $i$ alt og da altid $i$ den præcise betydning af menne-

20. Affergan: Exotisme et altérité, op. cit., p. 70 .

2I. Man kunne argumentere for, at Fredags tale i dialogen med Robinson fungerer som en fremsilling af det empifortolknin. Som etmografen kan fortelleren træde ud af dialogen og fortolke materialet.

22. I den oprindelige version lyder det gebrokne engelsk således: „You do great deal much good, says he, you teach wild mans be good sober tame mans", Daniel Defoe: The Life and Strange Surprizing Adventures of Robinson Crusoe... (ed. by John Man). London: Everyman, 1994, p. 184. 23. Den sorte legende er betegnelsen for den fortalling om de spanske conquistadores grusomme fremferd, der L'Amérique espagnole pue et revée. Les livres de vorages de Christophe Colomb à Bougainville. Paris: Promodis, I985). Lestringant peger på, at denne fortælling forstarkes $i$ RC af en pregnant puritansk antikatolicisme, der frrst og fremmest tager afstand fra den katolske forstålse af transsubstantiation i nadveren (Frank Lestringant: Cannibals. The Discovery and Representation of the Cannibal from Columbus to Jules Verme. Berkeley: University of California Press, 1997). folge Lestringant relaterer puritaneme transsubstantiatio-

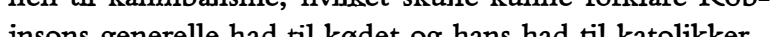
24 John Locke: Two Treatises on Government [I680]. London: Everyman, 1993, P. I30.

25. Det er i øvrigt i kraft af sin position som forteller, at Robinson indtager rollen som den fuldkomne bemestrer. Gennem fortallingen kan han indtage forsynets plads. 26. Det er værd at notere sig, at fornuftens sejr relateres til en skriveproces (,I drew up the state of affairs in writing", p. 54). Fornuften udtrykker sig gennem skriften hvorimod passionen udtrykker sig gennem kroppen. 27. Jean-Michel Racaut: l'Utopie narrative en France et en
Angleterre 1675-1761. Oxford: The Voltaire Foundation I991, p. I4.

199I, P. I4.
28. Horst Brunner: Die poetische Insel: Inseln und Inselvorstellungen in der deutschen Literatur. Stuttgart: J. B. Metzler, I967, p. 66 